Genetics and Molecular Biology, 37, 1 (suppl), 285-293 (2014)

Copyright (C) 2014, Sociedade Brasileira de Genética. Printed in Brazil

www.sbg.org.br

Review Article

\title{
The new world of RNAs
}

Danyella Barbosa Dogini ${ }^{1}$, Vinícius D'Avila Bittencourt Pascoal ${ }^{2}$, Simoni Helena Avansini ${ }^{1}$, André Schwambach Vieira ${ }^{1}$, Tiago Campos Pereira ${ }^{3}$ and Iscia Lopes-Cendes ${ }^{1}$

${ }^{1}$ Departamento de Genética Médica, Faculdade de Ciências Médicas, Universidade Estadual de Campinas, Campinas, SP, Brazil.

${ }^{2}$ Faculdade de Ciências Básicas, Universidade Federal Fluminense, Nova Friburgo, RJ, Brazil.

${ }^{3}$ Departamento de Biologia, Faculdade de Filosofia Ciências e Letras de Ribeirão Preto,

Universidade de São Paulo, Ribeirão Preto, SP, Brazil.

\begin{abstract}
One of the major developments that resulted from the human genome sequencing projects was a better understanding of the role of non-coding RNAs (ncRNAs). NcRNAs are divided into several different categories according to size and function; however, one shared feature is that they are not translated into proteins. In this review, we will discuss relevant aspects of ncRNAs, focusing on two main types: i) microRNAs, which negatively regulate gene expression either by translational repression or target mRNA degradation, and ii) small interfering RNAs (siRNAs), which are involved in the biological process of RNA interference (RNAi). Our knowledge regarding these two types of ncRNAs has increased dramatically over the past decade, and they have a great potential to become therapeutic alternatives for a variety of human conditions.
\end{abstract}

Keywords: non-coding RNAs, microRNAs, RNA interferance, RNA-based drugs.

\section{Introduction}

One of the main goals of the Human Genome Project was to identify all human genes (Collins et al., 1998). It was estimated that the human genome contained approximately $100,000-150,000$ genes. However, only nearly 20,000 genes could be identified at the end of the project; therefore, protein-coding sequences represent only $1.5 \%$ of the human genome. The rest of the genome, approximately $98 \%$, was considered junk DNA because it is composed of sequences that are not translated into proteins. These sequences were believed to be mainly part of regulatory regions or non-coding regions that did not play an important role in cell function (Lander et al., 2001). These conclusions were based on the central dogma of molecular biology (Crick, 1958), which considers that all relevant information contained in the DNA will be transcribed into messenger RNA (mRNA) molecules that will be subsequently translated into proteins, which are the important molecular players in cell function (including the regulation of gene expression). The concept of two main classes of RNA molecules already existed: i) RNAs which were translated into proteins, i.e., mRNAs, and ii) the group of non-coding RNAs (ncRNAs), mainly comprising transfer

Send correspondence to Iscia Lopes-Cendes. Department of Medical Genetics, School of Medical Sciences, UNICAMP, 13083-887 Campinas, SP, Brazil. E-mail: icendes@ unicamp.br.
RNAs (tRNAs) and ribosomal RNAs (rRNAs). However, as additional studies were performed, it became clear that ncRNAs were much more abundant than expected, and they were present in several different organisms, with a particularly high abundance in Homo sapiens (Hüttenhofer et al., 2005). These findings prompted the development of a new specific field in molecular biology, the study of ncRNAs, which has become increasingly relevant in the past decade. As knowledge advances, it becomes clear that discoveries in the field of ncRNAs are likely to make significant contributions to the biomedical sciences, including the possibility of novel therapeutic alternatives for a variety of human conditions.

\section{Non-coding RNAs}

The length of ncRNAs can vary from 21 to several thousand nucleotides (nt) and these molecules are divided into i) long or large RNAs, such as transfer RNA, ribosomal RNA and X-inactive specific transcript RNA (XIST RNA), and ii) small ncRNAs, such as microRNAs (miRNAs), small interfering RNAs (siRNAs), repeat associated small interfering RNAs (rasiRNAs), small nucleolar RNAs (snoRNAs), small nuclear RNAs (snRNAs), piwiinteracting RNAs (piRNAs) and others (Gavazzo et al., 2013). Table 1 summarizes the different types of ncRNAs described, as well as some of their main characteristics. 
Table 1 - Different types, main characteristics and functions of non-coding RNAs.

\begin{tabular}{|c|c|c|c|}
\hline & & Mean size & Function \\
\hline \multirow[t]{3}{*}{ Long ncRNA } & Ribosomal RNA & $\sim 1.9 \mathrm{~kb}$ & Essential for protein synthesis \\
\hline & XIST RNA & $\sim 17 \mathrm{~kb}$ & Chromosome $\mathrm{X}$ inactivation \\
\hline & Other lncRNA & $>200 \mathrm{nt}$ & $\begin{array}{l}\text { Involved in epigenetic modification, post-transcriptional processing, modulation } \\
\text { of chromatin structure, etc. }\end{array}$ \\
\hline \multirow[t]{6}{*}{ Small ncRNA } & miRNAs & $18-21 \mathrm{nt}$ & Gene regulation \\
\hline & siRNA & $\sim 21 \mathrm{nt}$ & Gene regulation; defense against viruses and transposon activity \\
\hline & rasiRNA & $24-27 \mathrm{nt}$ & Orientation of heterochromatin in the formation of centromeres \\
\hline & snoRNA & $60-300 \mathrm{nt}$ & Methylation and pseudo uridylation of other RNAs \\
\hline & snRNA & $100-300 \mathrm{nt}$ & Involved in spliceosome complex \\
\hline & piRNA & $26-30 \mathrm{nt}$ & Regulation of transposon activity and chromatin state \\
\hline
\end{tabular}

siRNAs are approximately $21 \mathrm{nt}$ in length and are produced from the processing of double-stranded RNA molecules by the enzyme Dicer. SiRNAs are involved in gene regulation, as well as viral defense and transposon activity (Ghildiyal and Zamore, 2009; Malone and Hannon, 2009). rasiRNAs are approximately $24-27 \mathrm{nt}$ long and play a role in heterochromatin orientation during the formation of centromeres (Theurkauf et al., 2006; Josse et al., 2007). snoRNAs consist of approximately $80 \mathrm{nt}$ and are believed to be involved in the guidance of uridylation and/or site-specific methylation during ribosomal RNA maturation (Dieci et al., 2009; Taft et al., 2009); in addition, there is evidence that snoRNAs can also play a role in the regulation of gene expression (Matera et al., 2007). snRNAs have been shown to be part of the spliceosome complex (Peters and Robson, 2008; Tazi et al., 2009) and are important for removing introns from immature mRNAs (Valadkhan, 2005). piRNAs are approximately 26 to $30 \mathrm{nt}$ in length, are restricted to germ line cells and function with AGO and PIWI proteins to regulate transposon activity and chromatin states (Ghildiyal and Zamore, 2009; Malone and Hannon, 2009). PiRNAs are also highly expressed in mammalian cells at the pachytene stage (Megosh et al., 2006).

Next, we will present additional information about miRNAs and siRNAs, because these are better characterized in terms of their functions and their impact in human health and disease.

\section{microRNAs}

MicroRNAs (miRNAs) are small endogenous ncRNAs that regulate gene expression post- transcriptionally in a sequence-specific manner (Bartel, 2004). In 1993, Victor Ambros and colleagues observed a mutant strain of Caenorhabditis elegans that exhibited developmental abnormalities, such as the inability to form the vulva (Lee et al., 1993). These authors observed that the gene responsible for these phenotypes, lin-4, had two transcripts: one, which was more abundant and $61 \mathrm{nt}$ in length and a second $21 \mathrm{nt}$ transcript that was not translated. lin-14 was shown to encode a nuclear protein that participates in the regulation of the transition from the first (L1) to the second (L2) larval stages in C. elegans (Ruvkun and Giusto, 1989; Lee et al., 1993). Subsequent studies revealed that the $21 \mathrm{nt}$ transcript is complementary to the 3' untranslated region (3'UTR) of lin-14 and, most interestingly, negatively regulates the expression of lin-14 (Lee et al., 1993). Initially, these findings were not adequately appreciated by the scientific community, because it was believed to be a rare process occurring only in C. elegans. However, in 2000, another such $22 \mathrm{nt}$ non-coding RNA, let-7, was identified in C. elegans (Reinhart et al., 2000). Surprisingly, it was also found to be complementary to the 3'UTR of another gene, lin-41, promoting its translational knockdown. In addition, the let-7 sequence was shown to be highly conserved in most organisms, including non-nematodes (Pasquinelli et al., 2000). These findings officially started a new field of investigation in small ncRNAs, more specifically, miRNAs. Currently, the existence of miRNAs has been extensively shown in insects and mammals (Ambros, 2001; Ambros et al., 2003; Lagos-Quintana et al., 2003; Mattick and Makunin, 2005), and the database of miRNAs has registered approximately 25,000 sequences found in 32 organisms representing vertebrates, invertebrates, plants and viruses (http://www.mirbase.org/).

\section{miRNA biogenesis}

Most miRNAs described to date are transcribed from sequences present in intergenic regions (Lagos-Quintana et al., 2001; Lau et al., 2001), but 25\% of human miRNAs identified are located in intronic regions and are transcribed in the same direction as the pre-messenger RNA, leading to the hypothesis that these miRNAs may use the promoter region of mRNAs for their transcription (Aravin et al., 2003; Lai et al., 2003).

miRNAs are transcribed by RNA polymerase II from what are called MIR genes. The first intermediate transcripts are 'hairpin' molecules called pri-miR. Similar to mRNAs, these transcripts undergo capping and polyadenylation at the 5' and 3' ends of the transcript, respectively (Lee et al., 2002; Cai et al., 2004; Kim, 2005). 
Unlike mRNAs, miRNA maturation begins in the nucleus and finishes in the cytoplasm. In animals, the nuclear processing is performed by DROSHA, an RNase type III enzyme with endonucleolytic activity, which, in combination with PASHA (Lee et al., 2003), recognizes the 'hairpin' structure of the pri-miR and cleaves it. This generates a pre-miR of approximately 60-70 nt in length. Pre-miRs are transported to the cytoplasm by exportin-5 and the cofactor Ran-GTP (Yi et al., 2003; Lund et al., 2004; Shibata et al., 2006). Once in the cytoplasm, pre-miRs are processed by the enzyme DICER, thus generating dimeric miRNA:miRNA* molecules approximately $22 \mathrm{nt}$ in length (Hutvagner et al., 2001). Whereas mammals typically encode a single DICER that can generate several classes of small RNAs, Drosophila and C. elegans have two types of Dicer (Lee et al., 2004). Plants require multiple types of Dicers; four and six different classes of DICER-like (DCL) enzymes have been identified in Arabidopsis thaliana and rice, respectively. In Arabidopsis, DCL 2, 3 and 4 are involved in the formation of different species of siRNAs, whereas DCL 1 is exclusively responsible for the biogenesis of miRNAs (Bernstein et al., 2001). In addition, it has been demonstrated that each Dicer produces siRNAs with specific sizes: DCL2, DCL4 and DCL3 form siRNAs with 22, 24 and $21 \mathrm{nt}$, respectively (Xie et al., 2005; Deleris et al., 2006; Blevins et al., 2006). The cleavage performed by DICER and Drosha will ultimately define the dimer miRNA:miRNA* extremity; the strand with a lower free energy at the $5^{\prime}$ end is incorporated by RISC (RNA-induced silencing complex), while the other strand is degraded (Khvorova et al., 2003). The miRNA bound to the RISC structure is guided to the complementary sequence of the target mRNA. If the pairing is complete $(100 \%$ sequence complementarity between the miRNA and mRNA), the mRNA will be degraded; however, if the sequence is only partially complementary, this will result in translational inhibition of the mRNA (Cannell et al., 2008).

One unique aspect of miRNA regulation is its complexity. It has been observed that a single miRNA can regulate expression of different mRNAs. Additionally, one mRNA can be regulated by multiple miRNAs (Yanaihara et al., 2006). In C. elegans, the miRNA lin-4 regulates the expression of the lin-14 gene as well as the heterochronic gene lin-28. A homolog of lin-14 exists in animals, and in mouse and human cells, it is regulated by miR-125a and let-7b (Moss and Tang, 2003).

miRNAs can also be produced by an alternative pathway. In this new model, sequences present in introns are capable of being transcribed as miRNAs. This hypothesis is derived from experiments in which an analysis was performed in pooled sequences from Drosophila S2 cells, leading to the mapping of miR:miR* duplexes (Ruby et al., 2007). It is believed that nearly $80 \%$ of animal miRNAs are transcribed from introns, and these miRNAs are known as mirtrons (; Rodriguez et al., 2004; Kim and Kim, 2007;
Okamura et al., 2007; Ruby et al., 2007). The formation of mirtrons differs from classical miRNA biogenesis because it does not require DROSHA proteins (Han et al., 2006; Kim and Kim, 2007; Wang et al., 2007); instead, mirtrons require AGO1 proteins for maturity (Okamura et al., 2007).

The pathway through which miRNAs regulate mRNA translation involves the mechanism used by cells as a defense against exogenous mRNA (such as in a viral infection), called the post- transcriptional gene silencing (PTGS) pathway (Fire et al., 1998). When used as a defense mechanism, PTGS induces the cleavage of double-stranded RNA (dsRNA) and allows for translational inhibition of exogenous mRNA (Hamilton and Baulcombe, 1999). dsRNAs are cleaved into smaller molecules, small interfering RNAs (siRNAs), which are subsequently associated with RISC, leading to gene silencing by RNA interference (RNAi). This will be discussed in more detail in a later section.

\section{miRNA function}

MiRNAs exhibit temporal- and tissue-specific expression (Lagos-Quintana et al., 2002; Lagos-Quintana et al., 2003; Liu et al., 2005; Mehler and Mattick, 2006; Schratt et al., 2006). One of the first functions associated with miRNA was the temporal regulation of development (Lee et al., 1993; Wightman et al., 1993). Negative posttranscriptional regulation of lin-14 by the lin- 4 miRNA is essential for the formation of a temporal gradient of LIN -14 protein to ensure correct transition between the larval stages in C. elegans. The second miRNA discovered, let-7, also proved to be a key driver in the temporal pattern of development of C. elegans (Abrahante et al., 2003; Lin et al., 2003; Grosshans et al., 2005).

To date, it has been shown that miRNAs regulate the expression of at least $1 / 3$ of all human genes, and these are known to play an important role in several biological processes, including cell cycle regulation, apoptosis, cell differentiation, and embryonic development, etc. (Ketting et al., 2001; Wienholds et al., 2003Ambros, 2004; Bartel, 2004; Lee et al., 2004; Wienholds and Plasterk, 2005). Deregulation of miRNA expression is often associated with human cancers (Volinia et al., 2006; Lu et al., 2008) and can induce activation of oncogenes or inactivation of tumor suppressor genes (Esquela-Kerscher and Slack, 2006). DICER-deficient mice die because they lose their stem cell pluripotency (Bernstein et al., 2003). Experiments with mutant DICER-1 in Drosophila show that the miRNA pathway is critical for cell division and for the passage from the G1 phase to the S phase of the cell cycle (Hatfield et al., 2005). There is also evidence of miRNA involvement in metabolism as well as in the regulation of apoptosis. In flies, the miRNA bantam accelerates proliferation and prevents apoptosis by regulation of a proapoptotic gene, hid (Brennecke et al., 2003). In vertebrates, miR-375 is ex- 
pressed in pancreatic islets and suppresses the secretion of insulin induced by glucose (Poy et al., 2004).

miRNAs have also been shown to play an important role in myogenesis and cardiogenesis. miR-1 is conserved from worms to mammals and is highly expressed in human muscle, fly muscle and the mouse heart (Aboobaker et al., 2005; Zhao et al., 2005). Interestingly, knockdown of this miRNA in Drosophila does not affect the formation and function of muscles during the larval stages, but instead affects the formation of muscles during growth in the adult animal (Sokol and Ambros, 2005). These results clearly show the role of miRNAs not only during development but also for further growth and tissue maintenance.

The association between miRNA deregulation and the development of pathological states was first discovered through studies in the field of oncology. One of the initial findings that showed that miRNAs indeed play a role in the regulation of oncogenes came from studies in chronic lymphocytic leukemia (Calin et al., 2002). These studies showed that several human miRNA transcription sites are located in genomic regions involved in cancers, such as regions of chromosomal breakpoints and fragile sites (Calin et al., 2004). Further studies demonstrated that differential expression of miRNAs is associated with tumor formation (Michael et al., 2003; Calin et al., 2004, 2005; Lu et al., 2005). In a few cases, a correlation between specific miRNA expression patterns and cell type could be found (Lu et al., 2005). In addition, most miRNAs are found to be down-regulated in tumor tissue when compared with normal tissue, which may lead to loss of cell differentiation $(\mathrm{Lu}$ et al., 2005).

Recent studies have demonstrated that some viruses encode miRNAs (Pfeffer et al., 2004) and that in the Epstein-Barr virus (EBV), a member of the herpesvirus family, these miRNAs are encoded in intergenic regions at specific clusters (Edwards et al., 2008; Feederle et al., 2011). These virus-encoded miRNAs have been shown to regulate their own genes (Barth et al., 2008; Umbach et al., 2008), as well as genes involved in virus-cell interactions (Murphy et al., 2008), leading to a modulation of the host immune system (Stern-Ginossar et al., 2007). In this way, it has been demonstrated that the BHRF1 miRNA cluster plays an important role in the transition from the latent virus state by enhancing expansion of the virus reservoir and reducing the viral antigenic load (Feederle et al., 2011). Therefore, these features have the potential to facilitate persistence of the virus in the infected host and can be used as new therapeutic targets for the treatment of some EBVassociated lymphomas (Feederle et al., 2011).

To better understand the function of miRNAs, it is also important to know their regulatory targets (i.e., the genes regulated by specific miRNAs). Because it has been estimated that each miRNA could regulate a large number of targets (Kim, 2005; Baek et al., 2008), bioinformatic algorithms have become a powerful tool for identifying
miRNA-regulated genes and predicting gene function. Therefore, a large number of predictive algorithms are available, such as TargetScan (Lewis et al., 2003), miRanda (John et al., 2004), PicTar (Krek et al., 2005), RNA22 (Miranda, et al., 2006), PITA (Kertesz et al., 2007), DIANA-microT (Maragkakis et al., 2009) and Tarbase (Hsu et al., 2011). The main algorithm used to predict miRNA:mRNA interactions involves pairing of the 5' region of the miRNA - a 2-8 nt region known as the 'seed region' - to the 3' untranslated region (3'-UTR) of the mRNA (Thomson et al., 2011). However, evidence suggests that the miRNA seed region pairing is not always a reliable predictor of miRNA:mRNA interactions (Didiano and Hobert, 2006). Indeed, precision of these algorithms is estimated to be approximately $50 \%$ when tested against experimental-proven miRNA targets (Alexiou et al., 2009). Therefore, it is highly suggested that additional experiments should be performed to validate potential miRNA targets. These may include, but are not limited to, reporter gene assays, evaluation of miRNA and target mRNA co-expression (e.g., northern blotting, qPCR or in situ hybridization) and assessment of miRNA effects on target protein expression (e.g., ELISA, western blotting, immunohistochemistry) (Kertesz et al., 2007; Kuhn, et al., 2008; Nuovo, 2010; Thomson et al., 2011 Hébert and Nelson, 2012; Vergoulis et al., 2012).

\section{Small Interfering RNAs and RNA Interference}

RNAi is frequently used as a technique to promote effective and specific post-transcriptional gene silencing through the administration of double-stranded RNAs (dsRNAs). Although the phenomenon was first observed in plants and fungi, the clear triggering mechanism was originally reported in the nematode C. elegans (Fire et al., 1998). In this work, the authors observed that after injecting long dsRNA molecules into the worm's gonad, the matching target mRNA was destroyed and a corresponding phenotypical change could be subsequently observed (Fire et al., 1998).

After the initial description, RNAi was shown to be functional in nearly all eukaryotic species tested so far. Inded, RNAi has been shown to be widely present, from viruses, unicellular organisms, fungi, plants and other animals. The technology promoted a revolution in molecular biology and medical sciences because it can be used to identify gene function or to silence essential genes present in a pathogen. The impact of RNAi is such that less than a decade after the seminal report, the discoverers were awarded the Nobel Prize. Investors also noted the immense potential behind this technique. As a result, several biotechnology start-ups emerged, devoted to the development of RNAi-based therapies (Check, 2004; Bonetta, 2007; Osborne, 2007).

RNAi can be triggered by two main types of double stranded RNA molecules. The first class encompasses long 
molecules, approximately 300-800 base pairs (bp) in length, which may be produced by several processes, such as: i) RT-PCR followed by in vitro transcription (Goto et al., 2003), ii) expression from a cDNA cloned in special vectors (Kamath et al., 2001) or iii) a transgenic cassette (Chuang and Meyerowitz, 2000). These long dsRNAs are the molecules of choice when using the technology in non-mammalian models. Because dsRNAs longer than 30 bp promote lethal effects in mammalian cells, 21 nt RNA duplexes, known as siRNAs, are the molecule of choice for use in mammals (Elbashir et al., 2001). siRNAs can also be used in non-mammalian cells, but this molecule must be designed for the target gene and its functionality must first be tested in vitro.

RNAi can be used to create genetically modified animals in an attempt to recapitulate the null phenotype. Moreover, hypomorphic animals, i.e., displaying intermediate levels of mRNA knockdown (from 0.1 to $99 \%$ ), may also be generated via RNAi, because the efficiency of silencing can be controlled (Khvorova et al., 2003, Schwarz et al., 2003). Such genetic constructions, presenting intermediary phenotypes, may be of great biological value when the null animal is not viable (Baker et al., 2004).

RNAi is frequently used as a strategy to identify gene function, but there are many other possibilities: i) to combat of several classes of pathogens (viruses, Palliser et al., 2006; bacterial diseases, Escobar et al., 2001; parasites, Pereira et al., 2008), ii) to generate plants and animals of interest (Minton, 2004; Peng et al., 2006) and iii) to control genetic diseases and tumors (Ptasznik et al., 2004; Raoul et al., 2005). All these new developments have recently led to the first published human clinical trials, with very promising results (Koldehoff et al., 2007; Koldehoff and Elmaagacli, 2009; Davis et al,. 2010; DeVincenzo et al., 2010; Leachman et al., 2010).

\section{Future Directions}

Progress in the area of ncRNAs seems to have occurred faster than in any major biological discipline in recent memory. The field has moved from virtual ignorance about an abundant class of regulatory molecules to a reasonably advanced understanding of the mechanisms of miRNA biogenesis and an emerging consensus about the numbers of miRNAs and their targets in several species, including humans. Recently, miRNAs have been used as a biomarker for several diseases. This is one of the most promising approaches in the use of these molecules (Zho and Wang, 2010; Cheng et al., 2011; Ohyashiki et al., 2011).

RNAi has promoted an enormous advancement in the field of molecular biology in the past decade. This technique allows a fast, cost-effective and simple alternative to promote down-regulation of virtually any gene from many species. RNAi-based drugs constitute the next big gamble of pharmaceutical companies for two main reasons: i) the promise of being highly specific, because RNAi relies on total sequence complementarity, and ii) the fact that the associated pharmacodynamics may not be problematic, because RNA is a biological molecule. Therefore, it is very likely that RNAi may lead to innovative medical treatments in the near future.

\section{Acknowledgments}

Dr. Iscia Lopes-Cendes is supported by grants from FAPESP, FAPESP-CEPID (BRAINN), CNPq and EpimiRNA International Project.

\section{References}

Aboobaker AA, Tomancak P, Patel N, Rubin GM and Lai EC (2005) Drosophila microRNAs exhibit diverse spatial expression patterns during embryonic development. Proc Natl Acad Sci USA 102:18017-18022.

Abrahante JE, Daul AL, Li M, Volk ML, Tennessen JM, Miller EA and Rougvie AE (2003) The Caenorhabditis elegans hunchback-like gene lin-57/hbl-1 controls developmental time and is regulated by microRNAs. Dev Cell 4:625-637.

Alexiou P, Maragkakis M, Papadopoulos GL, Reczko M and Hatzigeorgiou AG (2009) Lost in translation: An assessment and perspective for computational microRNA target identification Bioinformatics 25:3049-3055.

Ambros V (2001) microRNAs: Tiny regulators with great potential. Cell 107:823-826.

Ambros V (2004) The functions of animal microRNAs. Nature 431:350-355.

Ambros V, Bartel B, Bartel DP, Burge CB, Carrington JC, Chen X, Dreyfuss G, Eddy SR, Griffiths-Jones S, Marshall M, et al. (2003) A uniform system for microRNA annotation. RNA 9:277-279.

Aravin AA, Lagos-Quintana M, Yalcin A, Zavolan M, Marks D, Snyder B, Gaasterland T, Meyer J and Tuschl T (2003) The small RNA profile during Drosophila melanogaster development. Dev Cell 5:337-350.

Baek D, Villen J, Shin C, Camargo FD, Gygi SP and Bartel DP (2008) The impact of microRNAs on protein output. Nature 455:64-71.

Baker DJ, Jeganathan KB, Cameron JD, Thompson M, Juneja S, Kopecka A, Kumar R, Jenkins RB, de Groen PC, Roche P, et al. (2004) BubR1 insufficiency causes early onset of aging-associated phenotypes and infertility in mice. Nat Genet 36:744-749.

Bartel DP (2004) MicroRNAs: Genomics, biogenesis, mechanism and functions. Cell 23:281-297.

Barth S, Pfuhl T, Mamiani A, Ehses C, Roemer K, Kremmer E, Jäker C, Höck J, Meister G and Grässer FA (2008) Epstein-Barr virus-encoded microRNA miR-BART2 downregulates the viral DNA polymerase BALF5. Nucleic Acids Res 36:666-675.

Bernstein E, Caudy AA, Hammond SM and Hannon GJ (2001) Role for a bidentate ribonuclease in the initiation step of RNA interference. Nature 409:363-366.

Bernstein E, Kim SY, Carmell MA, Murchison EP, Alcorn H, Li MZ, Mills AA, Elledge SJ, Anderson KV and Hannon GJ (2003) Dicer is essential for mouse development. Nat Genet $35: 215-217$. 
Blevins T, Rajeswaran R, Shivaprasad PV, Beknazariants D, Si-Ammour A, Park HS, Vazquez F, Robertson D, Meins Jr F, Hohn T, et al. (2006) Four plant Dicers mediate viral small RNA biogenesis and DNA virus induced silencing. Nucleic Acids Res 34:6233-6246.

Bonetta L (2007) Three researchers developing therapies based on RNA interference talk about their experiences leaving academia for biotech companies. Biotechniques 42:10-11.

Brennecke J, Hipfner DR, Stark A, Russell RB and Cohen SM (2003) bantam encodes a developmentally regulated micro-RNA that controls cell proliferation and regulates the proapoptotic gene hid in Drosophila. Cell 113:25-36.

Cai X, Hagedorn C and Cullen B (2004) Human microRNAs are processed from capped, polyadenylated transcripts that can also function as mRNAs. RNA 10:1957-1966.

Calin GA, Dumitru CD, Shimizu M, Bichi R, Zupo S, Noch E, Aldler H, Rattan S, Keating M, Rai K, et al. (2002) Frequent deletions and down-regulation of micro-RNA genes miR15 and miR16 at 13q14 in chronic lymphocytic leukemia. Proc Natl Acad Sci USA 99:15524-15529.

Calin GA, Liu CG, Sevignani C, Ferracin M, Felli N, Dumitru CD, Shimizu M, Cimmino A, Zupo S, Dono M, et al. (2004) MicroRNA profiling reveals distinct signatures in B cell chronic lymphocytic leukemias. Proc Natl Acad Sci USA 101:11755-11760.

Calin GA, Ferracin M, Cimmino A, Di Leva G, Shimizu M, Wojcik SE, Iorio MV, Visone R, Sever NI, Fabbri M, et al. (2005) A microRNA signature associated with prognosis and progression in chronic lymphocytic leukemia. N Engl J Med 353:1793-1801.

Cannell IG, Kong YW and Bushell M (2008) How do microRNAs regulate gene expression? Biochem Soc Trans 36:12241231.

Check E (2004) RNA therapy beckons as firms prepare for clinical trials. Nature 429:792.

Cheng H, Zang L, Cogdell DE, Zheng H, Schetter AJ, Nykter M, Harris CC, Chen K, Hamilton SR and Zhang W (2011) Circulating plasma miR-141 is a novel biomarker for metastatic colon cancer and predicts poor prognosis. PLoS One 6:e17745.

Chuang CF and Meyerowitz EM (2000) Specific and heritable genetic interference by double-stranded RNA in Arabidopsis thaliana. Proc Natl Acad Sci USA 97:4985-4990.

Collins FS, Patrinos A, Jordan E, Chakravarti A, Gesteland R and Walters L (1998) New goals for the U.S. Human Genome Project: 1998-2003. Science 282:682-689.

Crick FH (1958) On protein synthesis. Symp Soc Exp Biol 12:138-163.

Davis ME, Zuckerman JE, Choi CH, Seligson D, Tolcher A, Alabi CA, Yen Y, Heidel JD and Ribas A (2010) Evidence of RNAi in humans from systemically administered siRNA via targeted nanoparticles. Nature 464:1067-1070.

Deleris A, Gallego-Bartolome J, Bao J, Kasschau KD, Carrington JC and Voinnet O (2006) Hierarchial action and inhibition of plant Dicer-like proteins in antiviral defense. Science 303:68-71.

DeVincenzo J, Lambkin-Williams R, Wilkinson T, Cehelskyd J, Nochur S, Walsh E, Meyersd R, Gollob J and Vaishnaw A (2010) A randomized, double-blind, placebo-controlled study of an RNAi-based therapy directed against respiratory syncytial virus Proc Natl Acad Sci USA 107:8800-8805.
Didiano D and Hobert (2006) Perfect seed pairing is not a generally reliable predictor for miRNA-target interactions. Nat Struct Mol Biol 13:849-851.

Dieci G, Preti M and Montanini B (2009) Eukaryotic snoRNAs: A paradigm for gene expression flexibility. Genomics 94:8388.

Edwards RH, Marquitz AR and Raab-Traub N (2008) EpsteinBarr Virus BART microRNAs are produced from a large intron prior to aplicing. J Virol 82:9094-9106.

Elbashir SM, Harborth J, Lendeckel W, Yalcin A, Weber K and Tuschl T (2001) Duplexes of 21-nucleotide RNAs mediate RNA interference in cultured mammalian cells. Nature 411:494-498

Escobar MA, Civerolo EL, Summerfelt KR and Dandekar AM (2001) RNAi-mediated oncogene silencing confers resistance to crown gall tumorigenesis. Proc Natl Acad Sci USA 98:13437-13442

Esquela-Kerscher A and Slack FJ (2006) Oncomirs - microRNAs with a role in cancer. Nat Rev Cancer 6:259-269.

Feederle R, Linnstaedt SD, Bannert H, Lips H, Bencun M, Cullen BR and Delecluse HJ (2011) A viral microRNA cluster strongly potentiates the transforming properties of a human herpesvirus. PLoS Pathog 7:e1001294.

Fire A, Xu S, Montgomery MK, Kostas SA, Driver SE and Mello CC (1998) Potent and specific genetic interference by double-stranded RNA in Caenorhabditis elegans. Nature 391:806-811.

Gavazzo P, Vassalli M, Costa D and Pagano A (2013) Novel ncRNAs transcribed by Pol III and elucidation of their functional relevance by biophysical approaches. Front Cell Neurosci 7:203-215.

Ghildiyal M and Zamore PD (2009) Small silencing RNAs: An expanding universe. Nat Rev Genet 10:94-108.

Goto A, Blandin S, Royet J, Reichhart JM and Levashina EA (2003) Silencing of Toll pathway components by direct injection of double-stranded RNA into Drosophila adult flies. Nucleic Acids Res 31:6619-6623.

Grosshans H, Johnson T, Reinert KL, Gerstein M and Slack FJ (2005) The temporal patterning microRNA let-7 regulates several transcription factors at the larval to adult transition in C. elegans. Dev Cell 8:321-330.

Hamilton AJ and Baulcombe DC (1999) A species of small antisense RNA in posttranscriptional genesilencing in plants. Science 286:950-952.

Han J, Lee Y, Yeom KH, Nam JW, Heo I, Rhee JK, Sohn SY, Cho Y, Zhang BT and Kim VN (2006) Molecular basis for the recognition of primary microRNAs by the Drosha-DGCR8 complex. Cell 125:887-901.

Hatfield SD, Shcherbata HR, Fischer KA, Nakahara K, Carthew RW and Ruohola-Baker H (2005) Stem cell division is regulated by the microRNA pathway. Nature 435:974-978.

Hébert SS and Nelson PT (2012) Studying microRNAs in the brain: Technical lessons learned from the first ten years. Exp Neurol 235:397-401.

Hsu SD, Lin FM, Wu WY, Liang C, Huang WC, Chan WL, Tsai WT, Chen GZ, Lee CJ, Chiu CM, et al. (2011) miRTarBase: A database curates experimentally validated microRNAtarget interactions. Nucleic Acids Res 39:D163-169.

Hüttenhofer A, Schattner P and Polacek N (2005) Non-coding RNAs: Hope or hype? Trends Genet 21:289-297. 
Hutvágner G, McLachlan J, Pasquinelli AE, Bálint E, Tuschl T and Zamore PD (2001) A cellular function for the RNAinterference enzyme Dicer in the maturation of the let-7 small temporal RNA. Science 293:834-838.

John B, Enright AJ, Aravin A, Tuschl T, Sander C and Marks DS (2004) Human microRNA targets. PLoS Biol 2:e363.

Josse T, Teysset L, Todeschini AL, Sidor CM, Anxolabéhère D and Ronsseray S (2007) Telomeric trans-silencing: An epigenetic repression combining RNA silencing and heterochromatin formation. PLoS Genet 3:1633-1643.

Kamath RS, Martinez-Campos M, Zipperlen P, Fraser AG and Ahringer J (2001) Effectiveness of specific RNA-mediated interference through ingested double-stranded RNA in Caenorhabditis elegans. Genome Biol 2:RESEARCH0002.

Kertesz M, Iovino N, Unnerstall U, Gaul U and Segal E (2007) The role of site accessibility in microRNA target recognition. Nat Genet 39:1278-1284.

Ketting RF, Fischer SE, Bernstein E, Sijen T, Hannon GJ and Plasterk RH (2001) Dicer functions in RNA interference and in synthesis of small RNA involved in developmental timing in C. elegans. Genes Dev 15:2654-2659.

Khvorova A, Reynolds A and Jayasena SD (2003) Functional siRNAs and miRNAs exhibit strand bias. Cell 115:209-216.

Kim VN (2005) MicroRNA biogenesis: Coordinated cropping and dicing. Nat Rev Mol Cell Biol 6:376-385.

Kim YK and Kim VN (2007) Processing of intronic microRNAs. EMBO J 26:775-783.

Koldehoff M and Elmaagacli AH (2009) Therapeutic targeting of gene expression by siRNAs directed against BCR-ABL transcripts in a patient with imatinib-resistant chronic myeloid leukemia. Methods Mol Biol 487:451-466.

Koldehoff M, Steckel NK, Beelen DW and Elmaagacli AH (2007) Therapeutic application of small interfering RNA directed against bcr-abl transcripts to a patient with imatinib-resistant chronic myeloid leukaemia. Clin Exp Med 7:47-55.

Krek A, Grün D, Poy MN, Wolf R, Rosenberg L, Epstein EJ, MacMenamin P, da Piedade I, Gunsalus KC, Stoffel M, et al. (2005) Combinatorial microRNA target predictions Nat Genet 37:495-500.

Kuhn DE, Martin MM, Feldman DS, Terry Jr AV, Nuovo GJ and Elton TS (2008) Experimental validation of miRNA targets. Methods 44:47-54.

Lagos-Quintana M, Rauhut R, Lendeckel W and Tuschl T (2001) Identification of novel genes coding for small expressed RNAs. Science 294:853-858.

Lagos-Quintana M, Rauhut R, Yalcin A, Meyer J, Lendeckel W and Tuschl $\mathrm{T}$ (2002) Identification of tissue-specific microRNAs from mouse. Curr Biol 12:735-739.

Lagos-Quintana M, Rauhut R, Meyer J, Borkhardt A and Tuschl T (2003) New microRNAs from mouse and human. RNA 9:175-179.

Lai EC, Tomancak P, Williams RW and Rubin GM (2003) Computational identification of Drosophila microRNA genes. Genome Biol 4:R42.

Lander ES, Linton LM, Birren B, Nusbaum C, Zody MC, Baldwin J, Devon K, Dewar K, Doyle M, FitzHugh W, et al. (2001) Initial sequencing and analysis of the human genome. Nature 409:860-921.

Lau NC, Lim LP, Weinstein EG and Bartel DP (2001) An abundant class of tiny RNAs with probable regulatory roles in Caenorhabditis elegans. Science 294:858-862.
Leachman SA, Hickerson RP, Schwartz ME, Bullough EE, Hutcherson SL, Boucher KM, Hansen CD, Eliason MJ, Srivatsa GS, Kornbrust DJ, et al. (2009) First-in-human mutation-targeted siRNA phase Ib trial of an inherited skin disorder. Mol Ther 18:442-446.

Lee RC, Feinbaum RL and Ambros V (1993) The C. elegans heterochronic gene lin-4 encodes small RNAs with antisense complementarity to lin-14. Cell 75:843-54.

Lee Y, Jeon K, Lee JT, Kim S and Kim VN (2002) MicroRNA maturation: Stepwise processing and subcellular localization. EMBO J 21:4663-4670.

Lee Y, Ahn C, Han J, Choi H, Kim J, Yim J, Lee J, Provost P, Rådmark O, Kim S, et al. (2003) The nuclear RNase III Drosha initiates microRNA processing. Nature 425:415419.

Lee YS, Nakahara K, Pham JW, Kim K, He Z, Sontheimer EJ and Carthew RW (2004) Distinct roles for Drosophila Dicer-1 and Dicer-2 in the siRNA/miRNA silencing pathways. Cell 117:69-81.

Lewis BP, Shih I, Jones-Rhoades MW, Bartel DP and Burge CB (2003) Prediction of mammalian microRNA targets. Cell 115:787-798.

Lin SY, Johnson SM, Abraham M, Vella MC, Pasquinelli A, Gamberi C, Gottlieb E and Slack FJ (2003) The C. elegans hunchback homolog, hbl-1, controls temporal patterning and is a probable microRNA target. Dev Cell 4:639-650.

Liu J, Valencia-Sanchez MA, Hannon GJ and Parker R (2005) MicroRNA-dependent localization of targeted mRNAs to mammalian P-bodies. Nat Cell Biol 7:719-723.

Lu Z, Liu M, Stribinskis V, Klinge CM, Ramos KS, Colburn NH and Li Y (2008) MicroRNA-21 promotes cell transformation by targeting the programmed cell death 4 gene. Oncogene 31:4373-4379.

Lu J, Getz G, Miska EA, Alvarez-Saavedra E, Lamb J, Peck D, Sweet-Cordero A, Ebert BL, Mak RH, Ferrando AA, et al. (2005) MicroRNA expression profiles classify human cancers. Nature 435:834-838.

Lund E, Guttinger S, Calado A, Dahlberg JE and Kutay U (2004) Nuclear export of microRNA precursors. Science 303:9598.

Malone C and Hannon G (2009) Small RNAs as guardians of the genome. Cell 136:656-668.

Maragkakis M, Alexiou P, Papadopoulos GL, Reczko M, Dalamagas T, Giannopoulos G, Goumas G, Koukis E, Kourtis K, Simossis VA, et al. (2009) Accurate microRNA target prediction correlates with protein repression levels. BMC Bioinformatics 10:e295.

Matera AG, Terns RM and Terns MP (2007) Non-coding RNAs: Lessons from the small nuclear and small nucleolar RNAs. Nat Rev Mol Cell Biol 8:209-220.

Mattick JS and Makunin IV (2005) Small regulatory RNAs in mammals. Hum Mol Genet 14(Spec No 1):R121-132.

Megosh HB, Cox DN, Campbell C and Lin H (2006) The role of PIWI and the miRNA machinery in Drosophila germline determination. Curr Biol 16:1884-1894.

Mehler MF and Mattick JS (2006) Non-coding RNAs in the nervous system. J Physiol 575:333-341.

Michael MZ, O'Connor SM, van Holst Pellekaan NG, Young GP and James RJ (2003) Reduced accumulation of specific microRNAs in colorectal neoplasia. Mol Cancer Res 1:882891. 
Minton K (2004) In the news: Allergen-free cats (Research Highlight). Nat Rev Immunol 4:926.

Miranda KC, Huynh T, Tay Y, Ang YS, Tam WL, Thomson AM, Lim B and Rigoutsos I (2006) A pattern-based method for the identification of microRNA binding sites and their corresponding heteroduplexes Cell 126:1203-1217.

Moss EG and Tang L (2003) Conservation of the heterochronic regulator Lin-28, its developmental expression and microRNA complementary sites. Dev Biol 258:432-442.

Murphy E, Vanicek J, Robins H, Shenk T and Levine AJ (2008) Suppression of immediate-early viral gene expression by herpesvirus-coded microRNAs: Implications for latency. Proc Natl Acad Sci USA 105:5453-5458.

Nuovo GJ (2010) In situ detection of microRNAs in paraffin embedded, formalin fixed tissues and the co-localization of their putative targets. Methods 52:307-315.

Ohyashiki K, Umezu T, Yoshisawa S-I, Ito Y, Ohyashiki M, Kawashima H, Tanaka M, Kuroda M and Ohyashiki JH (2011) Clinical impact of down-regulated plasma levels of miR-92a levels in non-Hodgkins lymphoma. PLOS One 2:e16408.

Okamura K, Hagen JW, Duan H, Tyler DM and Lai EC (2007) The mirtron pathway generates microRNA-class regulatory RNAs in Drosophila. Cell 130:1-12.

Osborne R (2007) Companies jostle for lead in RNAi, despite uncertainties. Nat Biotechnol 25:1191-1192.

Palliser D, Chowdhury D, Wang QY, Lee SJ, Bronson RT, Knipe DM and Lieberman J (2006) An siRNA-based microbicide protects mice from lethal herpes simplex virus 2 infection. Nature 439:89-94

Pasquinelli AE, Reinhart BJ, Slack F, Martindale MQ, Kuroda MI, Maller B, Hayward DC, Ball EE, Degnan B, Müller P, et al. (2000) Conservation of the sequence and temporal expression of let-7 heterochronic regulatory RNA. Nature 408:86-89.

Peng S, York JP and Zhang P (2006) A transgenic approach for RNA interference-based genetic screening in mice.Proc Natl Acad Sci USA 103:2252-2256.

Pereira TC, Pascoal VD, Marchesini RB, Maia IG, Magalhães LA, Zanotti-Magalhães EM and Lopes-Cendes I (2008) Schistosoma mansoni: Evaluation of an RNAi-based treatment targeting HGPRTase gene. Exp Parasitol 118:619-623.

Peters J and Robson JE (2008) Imprinted noncoding RNAs. Mamm Genome 19:493-502.

Pfeffer S, Zavolan M, Grässer FA, Chien M, Russo JJ, Ju J, John B, Enright AJ, Marks D, Sander C and Tuschl T (2004) Identification of virus-encoded microRNAs. Science 304:734736.

Poy MN, Eliasson L, Krutzfeldt J, Kuwajima S, Ma X, Macdonald PE, Pfeffer S, Tuschl T, Rajewsky N, Rorsman P, et al. (2004) A pancreatic islet-specific microRNA regulates insulin secretion. Nature 432:226-230.

Ptasznik A, Nakata Y, Kalota A, Emerson SG and Gewirtz AM (2004) Short interfering RNA (siRNA) targeting the Lyn kinase induces apoptosis in primary, and drug-resistant, BCR-ABL1(+) leukemia cells. Nat Med 10:1187-1189.

Raoul C, Abbas-Terki T, Bensadoun JC, Guillot S, Haase G, Szulc J, Henderson CE and Aebischer P (2005) Lentiviralmediated silencing of SOD1 through RNA interference retards disease onset and progression in a mouse model of ALS. Nat Med 11:423-428.
Reinhart BJ, Slack FJ, Basson M, Pasquinelli AE, Bettinger JC, Rougvie AE, Horvitz HR and Ruvkun G (2000) The 21nucleotide let-7 RNA regulates developmental timing in Caenorhabditis elegans. Nature 403:901-906.

Rodriguez A, Griffith-Jones S, Ashurst JL and Bradley A (2004) Identification of mammalian microRNA host genes and transcription units. Genome Res 14:1902-1910.

Ruby JG, Jan CH and Bartel DP (2007) Intronic microRNA precursors that bypass Drosha processing. Nature 448:83-86

Ruvkun G and Giusto J (1989) The Caenorhabditis elegans heterochronic gene lin-14 encodes a nuclear protein that forms a temporal developmental switch. Nature 338:313-319.

Schratt GM, Tuebing F, Nigh EA, Kane CG, Sabatini ME, Kiebler $M$ and Greenberg ME (2006) A brain-specific microRNA regulates dendritic spine development. Nature 439:283-289.

Schwarz DS, Hutvágner G, Du T, Xu Z, Aronin N and Zamore PD (2003) Asymmetry in the assembly of the RNAi enzyme complex. Cell 115:199-208.

Shibata S, Sasaki M, Miki T, Shimamoto A, Furuichi Y, Katahira J and Yoneda Y (2006) Exportin-5 orthologues are functionally divergent among species. Nucleic Acids Res 34:47114721

Sokol NS and Ambros V (2005) Mesodermally expressed Drosophila microRNA-1 is regulated by Twist and is required in muscles during larval growth. Genes Dev 19:2343-2354.

Stern-Ginossar N, Elefant N, Zimmermann A, Wolf DG, Saleh N, Biton M, Horwitz E, Prokocimer Z, Prichard M, Hahn G, et al. (2007) Host immune system gene targeting by a viral miRNA. Science 317:376-381.

Taft RJ, Glazov EA, Lassmann T, Hayashizaki Y, Carninci P and Mattick JS (2009) Small RNAs derived from snoRNAs. RNA 15:1233-1240.

Tazi J, Bakkour N and Stamm S (2009) Alternative splicing and disease. Biochim Biophys Acta 1792:14-26.

Theurkauf WE, Klattenhoff C, Bratu DP, McGinnis-Schultz N, Koppetsch BS and Cook HA (2006) rasiRNAs, DNA damage, and embryonic axis specification. Cold Spring Harb Symp Quant Biol 71:171-180.

Thomson DW, Bracken CP and Goodall GJ (2011) Experimental strategies for microRNA target identification. Nucleic Acids Res 39:6845-6853.

Umbach JL, Kramer MF, Jurak I, Karnowski HW, Coen DM and Cullen BR (2008) MicroRNAs expressed by herpes simplex virus 1 during latent infection regulate viral mRNAs. Nature 454:780-783.

Valadkhan S (2005) snRNAs as the catalysts of pre-mRNA splicing. Curr Opin Chem Biol 9:603-608.

Vergoulis T, Vlachos IS, Alexiou P, Georgakilas G, Maragkakis M, Reczko M, Gerangelos S, Koziris N, Dalamagas T and Hatzigeorgiou AG (2012) TarBase 6.0: Capturing the exponential growth of miRNA targets with experimental support. Nucleic Acids Res 40:D222-229.

Volinia S, Calin GA, Liu CG, Ambs S, Cimmino A, Petrocca F, Visone R, Iorio M, Roldo C, Ferracin M, et al. (2006) A microRNA expression signature of human solid tumors defines cancer gene targets. Proc Natl Acad Sci USA 103:2257-2261.

Wang Y, Medvid R, Melton C, Jaenisch R and Blelloch R (2007) DGCR8 is essential for microRNA biogenesis and silencing of embryonic stem cell self-renewal. Nat Genet 39:380-385. 
Wienholds E and Plasterk RH (2005) MicroRNA function in animal development. FEBS Lett 597:5911-5922.

Wienholds E, Koudijs MJ, van Eeden FJ, Cuppen E and Plasterk RH (2003) The microRNA-producing enzyme Dicer1 is essential for zebrafish development. Nat Genet 35:217-218.

Wightman B, Ha I and Ruvkun G (1993) Posttranscriptional regulation of the heterochronic gene lin-14 by lin- 4 mediates temporal pattern formation in C. elegans. Cell 75:855-862.

Xie Z, Allen E, Wilken A and Carrington JC (2005) Dicer-like 4 functions in trans-acting small interfering RNA biogenesis and vegetative phase change in Arabidopsis thaliana. Proc Natl Acad Sci USA 102:12984-12989.

Yanaihara N, Caplen N, Bowman E, Seike M, Kumanoto K, Yi M, Stephens RM, Okamoto A, Yokota J, Tanaka T, et al. (2006)
Unique microRNA molecular profiles in lung cancer diagnosis and prognosis. Cancer Cell 9:189-198.

Yi R, Qin Y, Macara IG and Cullen BR (2003) Exportin-5 mediates the nuclear export of pre-microRNAs and short hairpin RNAs. Genes Dev 173011-3016.

Zhao Y, Samal E and Srivastava D (2005) Serum response factor regulates a muscle-specific microRNA that targets Hand2 during cardiogenesis. Nature 436:214-220.

Zho S-L and Wang L-D (2010) Circulating microRNAs: Novel biomarkers for esophageal cancer. World J Gastroenterol 16:2348-2354.

License information: This is an open-access article distributed under the terms of the Creative Commons Attribution License, which permits unrestricted use, distribution, and reproduction in any medium, provided the original work is properly cited. 